\title{
Proliferation-inhibiting pathways in liver regeneration (Review)
}

\author{
MENGGANG LIU and PING CHEN
}

Department of Hepatobiliary Surgery, Daping Hospital, The Third Military Medical University, Chongqing 400042, P.R. China

Received March 25, 2016; Accepted March 13, 2017

DOI: $10.3892 / \mathrm{mmr} .2017 .6613$

\begin{abstract}
Liver regeneration, an orchestrated process, is the primary compensatory mechanism following liver injury caused by various factors. The process of liver regeneration consists of three stages: Initiation, proliferation and termination. Proliferation-promoting factors, which stimulate the recovery of mitosis in quiescent hepatocytes, are essential in the initiation and proliferation steps of liver regeneration. Proliferation-promoting factors act as the 'motor' of liver regeneration, whereas proliferation inhibitors arrest cell proliferation when the remnant liver reaches a suitable size. Certain proliferation inhibitors are also expressed and activated in the first two steps of liver regeneration. Anti-proliferation factors, acting as a 'brake', control the speed of proliferation and determine the terminal point of liver regeneration. Furthermore, anti-proliferation factors function as a 'steering-wheel', ensuring that the regeneration process proceeds in the right direction by preventing proliferation in the wrong direction, as occurs in oncogenesis. Therefore, proliferation inhibitors to ensure safe and stable liver regeneration are as important as proliferation-promoting factors. Cytokines, including transforming growth factor- $\beta$ and interleukin-1, and tumor suppressor genes, including p53 and p21, are important members of the proliferation inhibitor family in liver regeneration. Certain anti-proliferation factors are involved in the process of gene expression and protein modification. The suppression of liver regeneration led by metabolism, hormone activity and pathological performance have been reviewed previously. However, less is known regarding the proliferation inhibitors of liver regeneration and further investigations are required. Detailed information regarding the majority of known anti-proliferation signaling pathways also remains fragmented. The present review aimed to understand the signalling pathways that inhbit proliferation in the process of liver regeneration.
\end{abstract}

Correspondence to: Professor Ping Chen, Department of Hepatobiliary Surgery, Daping Hospital, The Third Military Medical University, 10 Changjiangzhilu Daping, Yuzhong, Chongqing 400042, P.R. China

E-mail: chenping10701@hotmail.com

Key words: liver injury, liver regeneration, proliferation-inhibiting, oncogenesis, liver disease

\section{Contents}

1. Introduction

2. Cytokine-associated pathways

3. Oncogene-associated pathways

4. Gene expression regulation-associated pathways

5. MicroRNAs (miRNAs) and the inhibition of liver regeneration

6. Protein modification-associated pathways

7. Metabolism-associated pathways

8. Hormone-associated pathways

9. Pathological factors and liver regeneration

10. Other inhibitors of liver regeneration

11. Conclusion and outlook

\section{Introduction}

The liver, an organ with a complex structure and function, is damaged by various factors, including viruses, drugs, trauma, chemotoxicity and metabolic disorders. A reduction in liver mass and ischemia-reperfusion caused by surgery are also causes of liver injury in patients with diseases of the liver. The high regenerative potential is the primary mechanism by which the liver compensates for loss of weight and assists in recovery from injury. Reasonable control of liver regeneration is of substantial value in therapy for liver diseases.

There have been studies on liver regeneration for over a century with notable progress. The mechanisms of liver regeneration have been elucidated in detail and have benefited from the contribution of partial hepatectomy (PH) models, first established by Higgins and Anderson in 1931. The classic process of liver regeneration, which involves numerous genes, consists of three stages: Initiation, proliferation and termination (1). Hepatocytes leave their quiescent state, resulting in DNA synthesis, with the stimulation of priming signals, including interleukin (IL)-6, tumor necrosis factor- $\alpha$ (TNF- $\alpha$ ) and nitric oxide in the initiation step. The proliferation step is characterized by hepatocytes entering the G1 phase of the cell cycle, and mitogens, including hepatocyte growth factor (HGF), transforming growth factor (TGF)- $\alpha$ and epidermal growth factor (EGF), are essential in this step. When the remnant liver grows to a suitable volume, similar to that of the original liver, regeneration enters the termination step, during which stop and differentiation signals are involved. Compared with the initiation and proliferation steps, the termination step is less well understood. 
As is already known, the liver regeneration process is a well-orchestrated process requiring a balance between pro-proliferation and anti-proliferation factors. However, the majority of studies on liver regeneration have been associated with the regulation of initiation and proliferation-promoting signals, with less known regarding termination and growth inhibitors. The proliferation inhibitors act as a 'brake' and 'steering wheel' to control the speed and direction of liver regeneration. The remnant hepatocytes in the damaged liver do not stop growing to the correct size and the proliferation is not suppressed. In extreme cases, the proliferation of liver cells may lead to oncogenesis. For example, loss of the expression of suppressor of cytokine signaling (SOCS)3 enhances liver regeneration but allows hepatocellular carcinoma formation (2). Furthermore, certain growth inhibitors can themselves function as tumor suppressor genes, for example p53 and p21, which are essential for the inhibition of carcinogenesis from liver damage by chronic injury (3). The known proliferation-inhibiting factors and associated pathways are discussed in this review.

\section{Cytokine-associated pathways}

$T G F-\beta$. TGF- $\beta$ is the most well-known hepatocyte proliferation inhibitor and stop signal in the process of hepatic regeneration. There have been investigations on the association between TGF and liver regeneration for $>30$ years. Nakamura et al reported in 1985 that TGF- $\beta$ from platelets inhibited the DNA synthesis of adult rat hepatocytes induced by epidermal growth factor (EGF) in primary culture (4). The administration of platelet-derived TGF- $\beta$ has also been shown to suppress liver regeneration in a two-thirds $\mathrm{PH}$ rat model (5). The inhibition of TGF- $\beta 1$ with monoclonal antibody has been shown to enhance liver regeneration in a porcine model of partial portal vein ligation (6). A previous study also found that inhibiting the TGF- $\beta$ pathway with the TGF- $\beta$ type I receptor kinase inhibitor increased hepatocyte proliferation during acute liver damage (7).

Previous investigations demonstrated that TGF- $\beta$ is predominantly secreted by nonparenchymal cells, including hepatic stellate cells (HSCs), Kupffer cells (KCs) and platelets, in liver regeneration and modulates the proliferation of hepatocytes in a paracrine manner $(8,9)$. Subsequent studies reported that TGF- $\beta$ can also be expressed in regenerating hepatocytes $(10,11)$. The expression of TGF- $\beta$ was found to increase at $4 \mathrm{~h}$ and reached a peak $72 \mathrm{~h}$ following $\mathrm{PH}$ when DNA synthesis had stopped, suggesting that TGF- $\beta$ was involved in the inhibition and termination of liver regeneration $(8,12)$. Further evidence for the anti-proliferation function of TGF- $\beta 1$ includes the reduction in DNA synthesis in transgenic mice with overexpressed TGF- $\beta 1$ following PH (13). Although several members are included in the TGF- $\beta$ superfamily, the $\beta 1$ form is the most important subtype in regeneration $(10,12)$.

TGF- $\beta$ modulates the proliferation of hepatocytes through multiple mechanisms. The earliest mechanism to be identified is the inhibition of EGF-induced DNA synthesis by TGF- $\beta$ following its binding to TGF- $\beta$ receptors on the surface of hepatocytes $(8,11,14)$. Investigations found that TGF- $\beta$ receptors were single-pass transmembrane serine/threonine kinases. When the TGF- $\beta$ ligand binds to the complex of TGF- $\beta$ receptors, the receptor-regulated cytoplasmic small mothers against decpentaplegic (R-Smad) proteins are phosphorylated and accumulate in the nucleus. The accumulated Smads subsequently inhibit the transcription of several genes by interacting with DNA binding proteins and transcriptional regulators (15-18). Another study showed that the TGF- $\beta$ signaling may be inhibited by SnoN and Ski, Smad pathway inhibitors, during the proliferative phase of liver regeneration (19). Increased expression of TGF- $\beta$ and activation of Smad 2 have also been found in a T cell-mediated hepatitis model following $\mathrm{PH}$, and were associated with impaired hepatocellular proliferation (20). The activation of Smad2/3, which can be inhibited by $\mathrm{Smad} 7$, is required for TGF- $\beta$ to have an inhibitory role in liver regeneration (21). Only activated TGF- $\beta$ has the ability to inhibit cell proliferation, as reported by Schrum et al, who observed that activated TGF- $\beta$, but not latent TGF- $\beta$, affected liver regeneration (22). A previous study found that the activation of TGF- $\beta$ required the involvement of thrombospondin-1 (TSP-1). Significantly reduced TGF- $\beta /$ Smad signaling and accelerated hepatocyte proliferation were observed in mice with TSP-1 deficiency following PH (23).

With the exception of EGF, other proliferation-associated factors and signaling pathways can be affected by TGF- $\beta$. TGF- $\beta$ can inhibit the secretion of human hepatocyte growth factor (HGF), which is known to be a complete mitogen in the process of liver regeneration (24). DNA synthesis induced by TNF can also be inhibited by TGF- $\beta$ in cultured hepatocytes (25). The overexpression of TGF- $\beta 1$ was shown to inhibit the protein level of cdc25A, a cyclin-dependent kinase-activating tyrosine phosphatase, by enhancing the binding of histone deacetylase 1 to p130 in Alb-TGF- $\beta 1$ transgenic mice following PH (26). TGF- $\beta 1$ was found to inhibit DNA synthesis of the G1 stage in cultured hepatocytes treated with HGF and heparin-binding epidermal growth factor-like growth factor by decreasing the expression of cyclin $\mathrm{E}$ without affecting the activity of c-Met, epidermal growth factor receptor (EGFR) or mitogen-activated protein kinase (MAPK), or the expression of cyclin D1 (27). This indicated that TGF- $\beta 1$ has the ability to restrain the growth factor-induced signals between cyclin D1 and cyclin $\mathrm{E}$ (27).

Inducing cell apoptosis is important for TGF- $\beta$ to exert its anti-proliferative effect in liver regeneration. Studies have indicated that liver cell regeneration and atypical bile duct proliferation are associated with TGF- $\beta$ in fulminant hepatitis (28). The overexpression of activated TGF- $\beta$ by adenovirus vectors enhanced the apoptosis of hepatocytes, resulting in the death of rats following two-thirds $\mathrm{PH}$ (22). Enhanced apoptosis was also found to be accompanied by the overexpression of TGF- $\beta 1$ in tetracycline-controlled TGF- $\beta 1$ mice (29), whereas pro-apoptotic signals were suppressed by insulin-like growth factor binding protein-1 (30). In experiments performed by Samson et al, the overexpression of TGF- $\beta 1$ resulted in increased expression of c-Jun, a potential pro-apoptotic transcription factor, which indicated that TGF- $\beta 1$ induced hepatocyte apoptosis through a c-Jun-independent mechanism (31). The expression of TGF- $\beta 1$ increases the generation of ROS, an essential mediator of apoptosis, and induces the apoptosis of hepatocytes in liver regeneration, which is associated with promoting the generation of ROS from mitochondria and inducing cytochrome P450 1A1 (32). 
TGF- $\beta$ is also the target of other proliferation inhibiting factors in liver regeneration. Cation-independent mannose 6-phosphate receptor (CIMPR), an indirect negative regulator of hepatocyte growth, which has progressively overexpressed in liver regeneration $8 \mathrm{~h}$ after $\mathrm{PH}$, mediates the activation of latent pro-TGF- $\beta$ (33). A schematic diagram of the TGF- $\beta$ signaling pathway is shown in Fig. 1.

Activin, another member of the TGF- $\beta$ superfamily, which is structurally related to TGF- $\beta$, also has an inhibitory effect on hepatocyte proliferation and liver regeneration. Activin A, with a similar ability to that of TGF- $\beta$, inhibits EGF-induced DNA synthesis in an autocrine manner without competing with TGF- $\beta$ (34). A study by Schwal et al indicated that activin induced the apoptosis of hepatocytes in a different manner from that of TGF- $\beta$ (35). The administration of follistatin, an activin-binding protein that can inhibit the activity of activin, enhances liver regeneration following $\mathrm{PH}$ (35-37). The inhibitory effect of activin may also be inhibited by increased expression of SnoN and Ski, which are Smad pathway inhibitors, in early liver regeneration (19). The impairment of activin type I receptors has also been shown to increase DNA synthesis in hepatocytes, providing further evidence of the anti-proliferative function of activin (38).

IL-1. IL-1 is another significant negative regulator of cell proliferation in the process of liver regeneration. In 1988, Takahashi et al first reported that IL-1 may be involved in the suppression of liver regeneration on examining syngeneic spleen cells treated with poly I:C in a mouse PH model (39). Another study by Nakamura et al showed that IL-1 $\beta$ markedly inhibited DNA synthesis induced by insulin and EGF in cultured rat hepatocytes (40). Similar inhibition of cultured hepatocytes has also been found in other studies (41-43), and enhanced liver regeneration by FK506 can be inhibited by IL-1 (44). The increased expression of IL-1 impairs regeneration via an indirect mechanism in liver injury induced by endotoxin following hepatectomy (45). The mRNA expression of IL-1 $\alpha$ in the whole rat liver was found to be downregulated at $10 \mathrm{~h}$, and upregulated 24 and $48 \mathrm{~h}$ following $\mathrm{PH}$, suggesting an association between the expression of IL-1 and liver regeneration (46). Further experiments have revealed that sensitivity of hepatocytes isolated from the liver $24 \mathrm{~h}$ following $\mathrm{PH}$ was increased to the inhibition of IL-1, and the administration of exogenous IL-1 $\beta$ suppressed DNA synthesis at 0 and $12 \mathrm{~h}$ post-PH (46). Long-term examination of the expression of IL-1 in the liver in liver regeneration showed that the mRNA levels of IL-1 increased slowly and marginally following 30 and $80 \%$ hepatectomy (47). The increased expression of IL-1 $\beta$ was has also been observed in a shrinking liver lobe of a rat portal vein ligation model, indicating that IL-1 $\beta$ was involved in the process of cellular atrophy $(48,49)$. The expression of IL-1 $\beta$ was also increased in the regenerating impaired liver caused by deficiency in the expression of peroxisome proliferator-activated receptor $\alpha(50)$. The suppression of IL-1 $\beta$ by FR167653, a selective inhibitor, was shown to promote liver regeneration in rat models of classic $\mathrm{PH}(70 \%)$ and extended hepatectomy $(90 \%)(51,52)$. Hepatocyte proliferation was also found to be enhanced by recombinant human interleukin 1 receptor antagonist in a mouse model of acute liver injury induced by $\mathrm{CCl}_{4}(53)$.
IL-1 is secreted by nonparenchymal cells (NPCs) in the regenerating liver. Goss et al found that IL-1 is produced by KCs and regulated by prostaglandin E2 (PGE2) in the rat liver following PH $(54,55)$. Heparin and PGE1 also suppress the expression of IL-1 in KCs following PH (45). Increased mRNA levels of IL-1 $\alpha$ and $\beta$, which are associated with KCs and the spleen, were reported in liver NPCs between $30 \mathrm{~min}$ and $1 \mathrm{~h}$ following PH (56). Medium conditioned by nonparenchymal cells isolated from the regenerating liver inhibit DNA synthesis in primary rat hepatocytes induced by HGF, EGF and TGF- $\alpha$. This suppression is inhibited by either IL-1 receptor antagonist or by IL-1 $\alpha$ and $\beta$ antibodies (46).

Although studies on the association between IL-1 and liver regeneration have been performed, the inhibitory mechanism of IL-1 on liver regeneration remains to be fully elucidated. Several studies have shown that IL-1 receptor antagonist (IL-1Ra), a competitive inhibitor of IL-1 $\alpha$ and IL-1 $\beta$, and anti-inflammatory protein, inhibited the inhibition of IL-1 and facilitated liver regeneration, suggesting that IL-1R was required for the inhibitory action of IL-1 (53,57-59). IL-1 was found to contribute to the impairment of liver regeneration by reducing HGF and promoting TGF- $\beta$ release in reduced-size orthotopic liver transplantation models (59). A previous study showed that IL-1 $\beta$ inhibits the fibroblast growth factor (FGF)19 signaling pathway, which regulates cell growth and metabolism of hepatocytes in liver regeneration (60). IL-1 $\beta$ also inhibits the expression of $\beta$-Klotho, a co-receptor of FGF receptor 4 (FGFR4), with involvement of the c-Jun N-terminal kinase (JNK) and nuclear factor (NF)- $\mathrm{KB}$ pathways. The activation of extracellular signal-regulated kinase (Erk)1/2 and hepatocyte proliferation induced by FGF19 is also suppressed by IL-1 $\beta$.

IL-6. IL-6 is a multifunctional cytokine, which has been investigated extensively. It is a known classical triggering signal of liver regeneration following PH. The essential role of IL-6 and its mechanisms in the process of liver regeneration have been confirmed (61). IL-6 has been shown to act as a positive regulator of liver regeneration in the majority of studies, whereas it has also been shown that IL-6 impairs liver regeneration, which conflicts with the mainstream findings. IL-6 inhibits mature hepatocyte proliferation and DNA synthesis stimulated by TNF and EGF in primary culture $(25,42)$. Beyer and Theologides showed that IL-6 suppressed the DNA synthesis of hepatocytes at 3 days in vitro (43). The inhibitory effect of IL-6 in hepatocyte proliferation may be associated with induction of the expression of $\mathrm{p} 21$ in vitro (62).

Upregulated levels of IL-6 have been observed in a number of abnormal liver regeneration models. Increased blood levels of IL-6, which induce the expression of protein inhibitor of activated Stat-3 and the suppressor of cytokine signaling (SOCS)-1, were found to be associated with impairment of liver regeneration in a model of hepatic failure (63). Hyperstimulation with IL-6 also suppressed hepatocyte proliferation by inducing the expression of p21 in transgenic mice overexpressing the human soluble IL-6 receptor/gp80 following PH (64). The overexpression of STAT3, a downstream molecule of IL-6, was found to impair hepatocyte proliferation in fatty liver following PH (65). In addition, the suppression of hepatocyte proliferation was accompanied by 


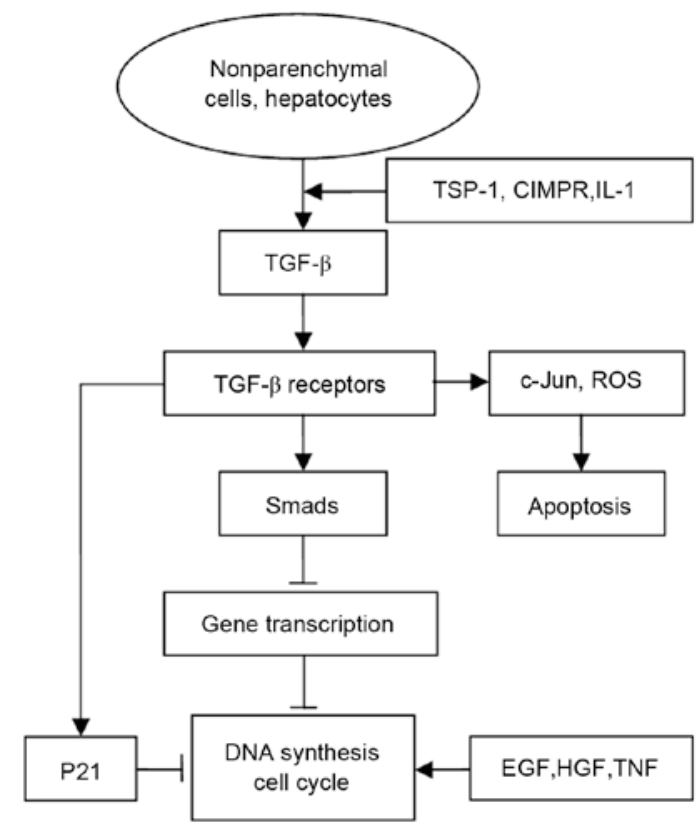

Figure 1. Schematic diagram of TGF- $\beta$ signaling pathways. TGF- $\beta$, transforming growth factor- $\beta$; Smads, small mothers against decapentaplegic; TSP-1, thrombospondin-1; CIMPR, cation-independent mannose 6-phosphate receptor; IL-1, interleukin-1; ROS, reactive oxygen speces; EGF, epidermal growth factor; HGF, hepatocyte growth factor; TNF, tumor necrosis factor.

increased levels of IL-6 in IL-1Ra-knockout mice following PH (57). The impairment of liver regeneration by hepatitis $B$ virus $\mathrm{X}$ protein $(\mathrm{HBx})$ via upregulating the expression of IL-6 was observed in an HBx-overexpressed transgenic mouse model (66). In addition to the data obtained in animal models, elevated levels of IL-6 have also been found in patients with chronic liver disease (67-70).

Although the mechanisms of IL-6 in liver regeneration are controversial, the majority of associated studies support the positive role of IL-6, with IL-6 affecting hepatocyte proliferation in a dose- and time-dependent manner $(71,72)$. The studies mentioned above also indicated that the inhibitory effects of IL-6 in liver regeneration, particulary on a background of liver disease, may be associated with its hyperstimulation of liver cells.

SOCS. SOCS is a family of proteins, which negatively regulate various cytokine signals (2). SOCS inhibits the activity of STAT3, a downstream signal of cytokines and growth factors in hepatic regeneration. SOCS3, a feedback inhibitor of the IL6/JAK/STAT3 pathway, is an important member of the SOCS family, which has received the most attention in investigations of liver regeneration. SOCS3 is transiently upregulated in the livers of mice following $\mathrm{PH}$ and is involved in the inactivation of STAT3 signaling (73-75). SOCS3 can inhibit the phosphorylation of gp130, a component of the IL-6 receptor, JAKs and STATs (76). SOCS3 hepatocyte-specific-knockout mice showed increased capability of cell proliferation and prolonged STAT3 phosphorylation following $\mathrm{PH}$, with enhanced activation of ERK1/2 also observed (77). SOCS3 can also negatively control the proliferative responses mediated by HGF and EGF (78). The overexpression of SOCS3 suppresses IL-22 signaling, another cytokine positively correlated with liver regeneration, via eliminating the IL-22-induced activation of STAT (79). The expression of SOCS3 is primarily induced by IL-6 and is also upregulated by other factors, including TNF $\alpha$, IL-1, IL-22 and ZIP14, a zinc transporter (73,79-81).

SOCS1, another member of the SOCS family, has a similar but weaker function to that of SOCS3 $(74,78)$. Unlike SOCS3, SOCS1 does not affect the growth signaling mediated by EGFR (78). A previous study indicated that SOCS1 negatively regulated the hepatocyte proliferation induced by HGF by inhibiting c-Met signaling (82).

IFN- $\gamma$. IFN- $\gamma$ can downregulate hepatocyte proliferation by activating STAT1 and its downstream genes, including RF-1, p21 and SOCS1, in liver regeneration (83). The inhibitory effect of invariant natural killer T (iNKT) cells, a major lymphocyte in the liver, was also associated with IFN- $\gamma(84)$. iNKT cells affect liver regeneration to a lesser degree. The deficiency of iNKT cells (CD1d and Jo281 cells) does not alter mouse liver regeneration following PH. However, treatment with $\alpha$-galactosylceramide, an inducer of iNKT cell activation, impairs hepatocyte proliferation via upregulating the expression of IFN- $\gamma$ in wild-type mice. Experiments also indicated that IL-4 is the primary mediator in the activation of iNKT cells and induction of IFN- $\gamma$ (84).

Other cytokines. There are other cytokines, which negatively regulate liver regeneration. TNF- $\alpha$, another pro-proliferation factor in liver regeneration, also has the ability to induce the apoptosis of adenovirus-infected hepatocytes in a coupled TGF- $\alpha$-IL- $\alpha / \beta$-IL-1ra autocrine cascade manner (85). The administration of $\alpha 2 b-I N F$ inhibits DNA biosynthesis and liver mass restitution by affecting the expression of cell cycle-associated genes, includin c-myc, p53 and c-erbB-2, in rat PH models (86). Further experiments have indicated that the suppression of hepatocyte proliferation depends on the time at which $\alpha 2 \mathrm{~b}$-IFN is administered (87), and the proliferation of hepatocytes was found to be inhibited by granulocyte colony-stimulating factor via upregulating the expression of IL-1 $\beta$ in a liver injury model induced with dimethylnitrosamine (88). Mice with single deficiency of myeloid differentiation factor 88 (MyD88), an adaptor protein for the majority of Toll-like receptors, presented with enhanced hepatocyte proliferation at 32 and $36 \mathrm{~h}$ post-PH (89). The decreased activation of STAT3 and induction of SOCS3 have also been detected in MyD88-null mice following PH (89). These results suggest that MyD88 has an antiproliferative effect in liver regeneration by affecting IL- 6 signaling pathways. A summary of the cytokines involved in inhibiting liver regeneration is presented in Table I.

\section{Oncogene-associated pathways}

P53. The role of $\mathrm{p} 53$, a negative regulator of growth and tumor suppressor genes, is complex in the process of liver regeneration and conclusions from different studies are contradictory. The expression of p53 is upregulated, corresponding to the $\mathrm{G} 1 / \mathrm{S}$ transition, in the early stage of liver regeneration following PH $(9,90)$. It has been shown that the overexpression of $\mathrm{p} 53$ by a transducing adenoviral vector encoding wild-type p53, did not affect the process of liver regeneration (91), however, 
Table I. Cytokines involved in inhibition of liver regeneration.

\begin{tabular}{llll}
\hline Cytokine & \multicolumn{1}{c}{ Source } & \multicolumn{1}{c}{ Upstream } & \multicolumn{1}{c}{ Downstream } \\
\hline TGF- $\beta$ & $\begin{array}{l}\text { NPCs (HSCs, } \\
\text { KCs and platelets) } \\
\text { hepatocytes }\end{array}$ & TSP-1, CIMPR, IL-1 & $\begin{array}{l}\text { TGF- } \beta \text { receptors, Smads (inhibit gene transcription) } \\
\text { c-Jun, ROS (promote apoptosis) }\end{array}$ \\
KCs & & Heparin, PGE1, & IL-1 receptor, TGF- $\beta$, FGF19, $\beta$-Klotho, \\
IFN- $\gamma$ & PGE2, G-CSF & JNK, NF- $\kappa$, Erk1/2 \\
$\alpha 2 b-I F N$ & Ectogenesis & IL-4 & STAT1 and downstream genes (RF-1, p21 and SOCS1) \\
G-CSF & Ectogenesis & IL-1 & Cell cycle-related genes (c-myc, p53 and c-erbB-2) \\
MyD88 & Hepatocytes & & STAT3 (inhibition), SOCS3 (induction) \\
\hline
\end{tabular}

TGF- $\beta$, transforming growth factor- $\beta$; IL-1, interleukin- 1 ; IFN, interferon; G-CSF, granulocyte colony-stimulating factor; MyD88, myeloid differentiation factor 88; TSP-1, thrombospondin-1; CIMPR, cation-independent mannose 6-phosphate receptor; ROS, reactive oxygen species;

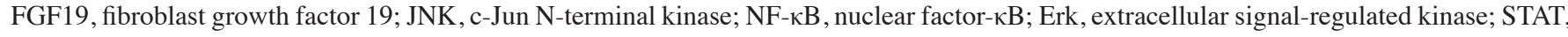
signal transducer and activator of transcription; SOCS, suppressor of cytokine signaling.

other studies showed that p53 may positively regulate hepatocyte proliferation in rats. The suppression of the expression of p53 results in the reduction of DNA replication in hepatocytes in vitro (92). A study by Inoue et al showed that the levels of p53 increased in cultured hepatocytes induced with HGF, and inhibiting the expression of p53 by an antisense oligonucleotide resulted in a decrease in the levels of TGF- $\alpha$ and of DNA synthesis (93). It was also found that upregulation of the expression of p53 was synchronous with HGF followed by an increase of TGF- $\alpha$ in a rat PH model, suggesting that p53 is positively correlated with liver regeneration (93).

However, other findings have supported that p53 negatively controls liver regeneration. Previous studies have provided indirect evidence of the anti-proliferation functions of p53. Suppressing p53 with antisense oligonucleotides enabled hepatocytes to recover from growth arrest induced by ultraviolet (94). Increased expression of p53, accompanied by a downregulation in the levels of proliferating cell nuclear antigen (PCNA), was observed in rats treated with a metallothionein antisense oligonucleotide, suggesting an inverse correlation between p53 and liver regeneration (95). The detailed role of p53 in liver regeneration was examined by Arora and Iversen (96). Increased weight gain of remnant-regenerating liver, CYP isoform activities and expression of PCNA were observed in rat $\mathrm{PH}$ models, in which the expression of p53 was inhibited with an antisense oligonucleotide, whereas the $G_{1}$ cell populations and levels of P21 were also reduced in the p53-inhibited rats, indicating that $\mathrm{p} 53$ controls hepatocyte proliferation in a cell cycle checkpoint manner (96). Furthermore, loss of the expression of p53 resulted in early entry into the cell cycle and prolonged the proliferation of hepatocytes in p53 (-/-) mice following $\mathrm{PH}$, and the inhibitory mechanism of p53 was correlated with the expression of mitotic genes, including Forkhead box M1, Aurka, Large tumor suppressor kinase 2, Polo like kinase (Plk)2 and Plk4 (97). Abrogation of the p53 pathways also facilitates liver regeneration in Wild-type p53-induced phosphatase 1-deficient mice following $\mathrm{PH}$ (98).

P53 can also suppress cell proliferation in regeneration of damaged liver on a background of chronic disease or drug treatment. An increased expression of p53 followed by the induction of p21 was associated with the inhibition of hepatocyte proliferation in $\mathrm{PH}$ models treated with 2-acetaminofluorene (99). Impaired liver regeneration and increased expression of $\mathrm{p} 21$ following partial $\mathrm{PH}$ was observed in mice lacking c-Jun, a key regulator of hepatocyte proliferation, whereas the activation of p53 eliminates the effect, indicating that p53 is a proliferation inhibitor in liver regeneration (100). The activation of a p53-dependent checkpoint correlates with premitotic arrest and abnormal cell death in transgenic mice overexpressing human Aurora-A following PH (101). The expression levels of p53 and p21 are also upregulated, coinciding with cell cycle arrest and apoptosis in hepatocytes of liver injury models induced by acetaminophen (102-104).

P21. P21, the expression product of the ras gene, also termed wide-type 53-activated factor 1 or cyclin-dependent kinase interacting protein 1 , has been identified as a cyclin-dependent kinase inhibitor and downstream gene of p53 (105-107). The negative control role of $\mathrm{p} 21$ has been confirmed in various studies. The expression of p21 increased maximally following peak hepatocyte DNA synthesis and cell division, later than that of p53, in rat and mouse PH models, indicating its association with the proliferation of liver cells $(90,108)$. The upregulation in levels of p21 have been examined not only hepatocytes, but also nonparenchymal cells, in the process of liver regeneration (109). In addition to the data mentioned above, overexpressed p21 also coincides with the arrestment of liver regenerating in several disease and drug toxicity models $(65,110-115)$.

Although p21 is a classic downstream signal of p53, the expression of p21 is induced by other factors in addition to p53 in liver regeneration. Increased mRNA levels of p21 induced by p53 were identified and involved in inhibiting hepatocyte proliferation in 2-acetaminofluorene-treated rats (120). Upregulated levels of p53 and p21 were also correlated with impaired liver regeneration in acute liver injury models induced by acetaminophen, and inhibition of the p53/p21 pathway promoted hepatocyte proliferation $(102,121)$. 
Table II. Oncogenes involved in inhibition of liver regeneration.

\begin{tabular}{|c|c|c|c|}
\hline Oncogene & Upstream & Downstream & Function \\
\hline P53 & & P21 (upregulating) & Cell cycle checkpoint \\
\hline $\mathrm{P} 21$ & $\begin{array}{l}\mathrm{P} 53, \mathrm{TGF}-\beta, \\
\text { activin } \mathrm{A}, \mathrm{C} / \mathrm{EBP} \alpha\end{array}$ & Cell cycle-related protein (downregulating) & Cell cycle checkpoint \\
\hline Bcl-2 & & p107, cyclin E (downregulating) & Negatively modulates cell cycle \\
\hline PUMA & & Bax, macrophage inflammatory protein-2 & Another member of the Bcl-2 family \\
\hline BI-1 & & Cell cycle-related protein (downregulating) & Negatively modulates cell cycle \\
\hline $\mathrm{P} 27$ & & CDK2 (downregulating) & Negatively modulates cell cycle \\
\hline Fas & & - & Induces apoptosis \\
\hline NDRG2 & & $\mathrm{P} 53 / \mathrm{p} 21$ & Negatively modulates cell cycle \\
\hline
\end{tabular}

TGF- $\beta$, transforming growth factor- $\beta$; C/EBP $\alpha$, CCAAT/enhancer-binding protein- $\alpha$ Bcl-2, B-cell lymphoma 2; PUMA, P53 upregulated modulator of apoptosis; BI-1, BAX, Bcl-2-associated X protein; BI-1, BAX inhibitor 1; CDK2, cyclin-dependent kinase 2; NDRG2, N-Myc downstream-regulated gene 2 .

However, no difference in the gene expression of p21 was found between p53-deficient and wild-type mice following $\mathrm{PH}$, although the post-transcriptional regulation may be associated with p53 (116). Furthermore, treatment with TGF- $\beta$ and activin A upregulated the expression of p21 in cultured primary hepatocytes (116). These data suggested that the induction of p21 is controlled in a p53-dependent and independent manner. Similar expression and localization of p21 was also found in wild-type and p53-null mice treated with carbon tetrachloride, and the increased levels of p21 might be correlated with CCAAT/enhancer-binding protein (C/EBP) (117). Other experiments have shown that levels of $\mathrm{p} 21$ were regulated by $\mathrm{C} / \mathrm{EBP} \alpha$ (122). Increased levels of p21 were observed in c-Jun-knockout mice following PH, and inactivation of the p53/p21 signaling pathway abrogated the suppression of liver regeneration, suggesting that the expression of p21 may be regulated by c-Jun (100).

B-cell lymphoma-2 (Bcl-2). Important in the proliferation of tumor cells, Bcl-2 also inhibits hepatocyte proliferation in liver regeneration. Bcl-2 transgenic mice show delayed hepatocyte DNA synthesis following $\mathrm{PH}$, and a similar result is observed in cultured liver cells. In addition, the overexpression of Bcl-2 is followed by decreased expression levels of p107 and cyclin $\mathrm{E}$ (123). These results indicate that Bcl-2 may be a negative cell cycle modulator in liver regeneration.

P53 upregulated modulator of apoptosis (PUMA), another member of the Bcl-2 family, is also negatively correlated with liver regeneration. PUMA is downregulated, accompanied by increased apoptosis and decreased proliferation, in the early phase post-PH (124). Bcl-2-associated X protein (Bax) inhibitor-1 (BI-1), which has a similar function to that of $\mathrm{Bcl}-2$ family proteins, also regulates liver cell proliferation in vivo. Enhanced liver regeneration, accompanied by the increased expression of cell cycle regulators, including cyclin D1, cyclin D3, Cdk2 and Cdk4, have been observed in BI-1-deficient mice following $\mathrm{PH}$ (125).

Other oncogene-associated pathways. Several studies have shown that additional oncogenes can inhibit liver regeneration.
P27 is also a tumor suppressor gene and cyclin-dependent kinase inhibitor. P27 was shown to be minimally expressed in the mouse liver following $\mathrm{PH}$ in a time-dependent manner, and p27 decreased the activity of CDK2 prior to and following peak DNA synthesis, suggesting its negative role in liver regeneration (108).

Fas, also known as APO-1 or CD95, and Fas ligand (FasL) are essential in cell apoptosis and regulate the proliferation of tumor cells (126). The expression of Fas decreased significantly immediately in the rat liver and had recovered gradually to a normal level of quiescent hepatocytes 14 days following $\mathrm{PH}$, suggesting that the Fas/ FasL system was also negatively correlated with liver regeneration (127).

N-Myc downstream-regulated gene 2 (NDRG2), is also a known tumor suppressor gene and its expression is reduced or undetectable in various types of tumor (128). The significant downregulation of NDRG2 was examined in regenerating livers, and the overexpression of NDRG2 resulted in a cell cycle arrest via upregulating the p53/p21 pathway and inhibiting cyclin E-Cdk2 activity (129). These data indicate that NDRG2 has a potential negative effect in liver regeneration. A summary of the oncogenes involved in inhibiting liver regeneration is presented in Table II.

\section{Gene expression regulation-associated pathways}

Transcription factor-associated pathways. Transcription factors important roles in liver regeneration, however, the majority of them positively regulate liver regeneration. Other transcription factors, which may have inhibitory roles in liver regeneration, are less well understood.

$\mathrm{C} / \mathrm{EBP} \alpha$, a member of the CCAAT enhancer-binding protein family, is expressed abundantly in the normal liver. However, the expression of $\mathrm{C} / \mathrm{EBP} \alpha$ was found to decrease markedly in proliferating cells following $\mathrm{PH}$ and in cultured hepatocytes stimulated with EGF and insulin, suggesting an inverse correlation between $\mathrm{C} / \mathrm{EBP} \alpha$ and liver regeneration (130). Positive correlation between $\mathrm{p} 21$ and $\mathrm{C} / \mathrm{EBP} \alpha$ has been observed in $\mathrm{C} / \mathrm{EBP} \alpha$-knockout mice. $\mathrm{C} / \mathrm{EBP} \alpha$ did not affect the mRNA levels of p21 but inhibited the proteolytic 
Table III. Protein modification-associated pathways in liver regeneration inhibition.

\begin{tabular}{lll}
\hline Name & \multicolumn{1}{c}{ Downstream } & \multicolumn{1}{c}{ Function } \\
\hline SOCS & STAT3 & Downregulating STAT3 phosphorylation \\
PTP1B & JNK1/2, STAT3, EGFR, HGFR & Dephosphorylating tyrosine kinases \\
Hippo pathway & YAP & Inhibiting proliferation-associated transcription factors \\
PPM1A & Cyp3a11 & \\
Mig-6 & Protein kinase B, EGFR & Modulating phosphorylation of EGFR
\end{tabular}

SOCS, suppressor of cytokine signaling; STAT, signal transducer and activator of transcription; PTP1B, protein tyrosine phosphatase 1B; JNK, c-Jun N-terminal kinase; EGFR, epidermal growth factor receptor; HGFR, hepatocyte growth factor receptor; YAP, Yes-associated protein; PPM1A, $\mathrm{Mg}(2+) / \mathrm{Mn}(2+)$-dependent phosphatase 1A; Mig-6, mitogen-inducible gene-6.

degradation of $\mathrm{p} 21$, indicating that $\mathrm{C} / \mathrm{EBP} \alpha$ inhibited hepatocyte proliferation via controlling the expression of p21 in a post-transcriptional manner (122). In aged animal PH models, $\mathrm{C} / \mathrm{EBP} \alpha$ also suppressed the expression of E2F via forming the $\mathrm{C} / \mathrm{EBP} \alpha-\mathrm{Rb}-\mathrm{E} 2 \mathrm{~F} 4$ complex, which can bind to E2F-dependent promoters, inhibiting the expression of E2F and inhibiting cell proliferation (131).

Forkhead box (Fox)O1, a transcription factor regulated by Akt, may also be an anti-proliferative factor in liver regeneration. Deleting Akt1 and Akt2 was shown to result in impairment of liver regeneration in mice following $\mathrm{PH}$, whereas liver-specific deletion of FoxO1 reversed this effect, indicating that FoxO1 has a negative effect on liver regeneration (132).

\section{MicroRNAs (miRNAs) and the inhibition of liver regeneration}

MicroRNAs (miRNAs) have an effect on the post-transcriptional control of gene expression and their association with liver regeneration has attracted increasing interest. A number of miRNAs have been identified as liver regeneration inhibitors, including miR-26a, miR-33, miR-34a, miR-127, miR-150 and miR-378 (133).

\section{Protein modification-associated pathways}

Previous studies have shown that certain anti-proliferation inhibitors are involved in liver regeneration via regulating the protein modification of downstream molecules, including phosphorylation. Of note, SOCS, the natural terminators of cytokine signaling, are involved via regulating the phosphorylation of downstream molecules (76). Tyrosine phosphorylation-mediated signaling, including the EGF and HGF pathways, is required in liver regeneration, whereas protein tyrosine phosphatase 1B (PTP1B), a key regulator of metabolism and cell growth, is involved in the dephosphorylating process of the tyrosine kinase superfamily. PTP1B-deficient mice present with enhanced cell proliferation and increased phosphorylation of JNK1/2 and STAT3, the downstream molecules of TNF- $\alpha$ and IL-6, which trigger liver regeneration following PH (134). Similar phosphorylation was observed in wild-type cells following the silencing of PTP1B, whereas the overexpression of PTP1B led to the opposite result. Accumulated tyrosine phosphorylation of EGFR and hepatocyte growth factor receptor (HGFR), followed by increased activation of Akt and ERK, were also examined in PTP1B-/- mice following $\mathrm{PH}$. These data indicate that PTP1B negatively regulates liver regeneration via dephosphorylating key molecules of the signaling pathways, which promotes cell proliferation.

The Hippo pathway is a novel pathway, which is associated with organ size control and tumorigenesis (135). The Hippo pathway consists of several core kinases, including the mammalian Ste20-like kinases (Mst1/2) and Salvador 1, and activates large tumor suppressor (Lats1/2), exerting effects via a series of phosphorylating processes of these kinases. The final effect of the Hippo pathway is to phosphorylate and inhibit the activity of Yes-associated protein (YAP), a transcription co-activator, and the transcriptional co-activator with PDZ-binding motif, which regulates different proliferation-associated transcription factors. Increased activation of YAP has been found in the early stage of rat liver regeneration following PH, whereas the activation of Mst1/2 and Lats1/2 were downregulated at this time (136). The levels of YAP and Mst1/2 kinase returned to their normal levels, as in quiescent liver cells, when the liver size was almost restored, suggesting a negative role of the Hippo pathway in liver regeneration.

$\mathrm{Mg}(2+) / \mathrm{Mn}(2+)$-dependent phosphatase 1A (PPM1A) is another phosphatase identified in a previous study, which has inhibitory potential in liver regeneration. The expression of PPM1A was decreased, which was positively correlated with the expression of Cyp3a11 in the early stage of liver regeneration in mice (137). Furthermore, inhibition of the expression of PPM1A leads to the enhanced proliferation of HepG2 cells. The detailed mechanism of PPM1A in the control of liver regeneration requires further investigation in the future.

Mitogen-inducible gene-6 (mig-6), an adaptor protein associated with the modulation of receptor tyrosine kinases, including EGFR, is also known as receptor-associated late transducer, gene33 and Errfil $(138,139)$. In mig-6-knockout mice, accelerated hepatocyte proliferation is observed in the early stage of liver regeneration following PH. Downregulating the expression of mig- 6 also enhances EGFR signaling via the protein kinase B pathway in mouse PH models (140), suggesting that mig- 6 is a negative regulator in liver regeneration. A summary of the protein modification-associated pathways involved in the inhibiton of liver regeneration is shown in Table III. 


\section{Metabolism-associated pathways}

Metabolism is an important function of the liver and also affects the process of liver regeneration. Several metabolic factors have been reported to be associated with the impairment of liver regeneration. For example, very low-density lipoprotein has been shown to suppress hepatocyte proliferation in in vitro and in vivo experiments (141). The overadministration of glucose has also been shown to arrest DNA synthesis and cell cycle in liver injury models, indicating that glucose loading depresses liver regeneration (142).

S-adenosylmethionine (SAMe), the primary methyl donor in the liver, is important in the metabolism of cells and regulates cell proliferation. Adenosine monophosphate-activated protein kinase (AMPK), the principal energy sensor in cells, can be inhibited by SAMe. A study by Vazquez-Chantada et al showed that hepatocyte proliferation was inhibited by SAMe in mouse liver regeneration (143). SAMe inhibited the HGF-mediated phosphorylation of AMPK, which upregulated cytoplasmic HuR and certain cell cycle proteins, including cyclin D1 and A2 in liver cells. Furthermore, phosphorylation of the LKB1/AMPK/endothelial nitric oxide synthase cascade mediated by HGF was suppressed in mouse PH models pretreated with SAMe. Evidence of the inhibitory function of SAMe on AMPK and liver regeneration was also obtained in another study (144).

Sirtuin 1 (SIRT1) is an important metabolic modulator of gluconeogenesis, fat, protein and bile acid (BA), and is also associated with liver regeneration. Impaired hepatocyte proliferation accompanied by BA accumulation and damaged farnesoid X receptor (FXR) activity was observed in transgenic mice overexpressing SIRT1 following PH (145). The overexpression of SIRT1 resulted in the persistent deacetylation of FXR, which was inversed by 24-norursodeoxycholic acid, followed by decreased expression of FXR-target genes, including small heterodimer partner and bile salt export pump. These data indicate that SIRT1 may negatively regulate liver regeneration by controlling the metabolism of BA.

\section{Hormone-associated pathways}

The association between hormones and liver regeneration has been investigated in previous studies (146). Norepinephrine upregulates the level of TGF- $\beta$ via the $\alpha 1$-adrenergic receptor ( $\alpha 1-\mathrm{AR})$ in cultured rat hepatocytes (147). The levels of adrenal hormones are negatively correlated with DNA synthesis and cell cycle arrest, in a circadian manner, during liver regeneration in hepatectomized animals (148). The expression and function of $\alpha 1-\mathrm{AR}$ are decreased, in contrast to the increased level of $\beta 2-\mathrm{AR}$, in hepatocytes following PH. Of note, treatment with isoproterenol, a $\beta$-AR agonist, inhibits $3 \mathrm{H}$-thymidine incorporation of hepatocytes isolated from $\mathrm{PH}$ models via upregulating the activation of stress-activated protein kinase and inhibiting p42 MAP kinase. This was inhibited by propranolol, a $\beta$-AR antagonist (149).

Hydrocortisone treatment results in the persistent suppression of hepatocyte proliferation and increased expression of P21 in PH models (150). Pretreatment with dexamethasone also inhibits the proliferation of hepatocytes, accompanied by reduced expression levels of TNF and IL-6 (151). This suggests that glucocorticoid hormone has an inhibitory effect on liver regeneration. Short-term administration of ethinyl estradiol, a potent promoter of hepatocarcinogenesis in female rats, leads to an initial, transient increase in hepatocyte proliferation. However, long-term treatment with ethinyl estradiol results in the inhibition of liver regeneration, without affecting DNA synthesis, following PH (152). Somatostatin also inhibits DNA synthesis induced by HGF and EGF via a cAMP-independent mechanism, indicating that it may be a potent inhibitor of liver regeneration (153).

\section{Pathological factors and liver regeneration}

Pathological alterations caused by various factors, including ethanol, drugs and hepacivirus, on liver regeneration is generally accepted. The abnormal expression of cytokines and proliferative inhibitors, induced by acute or chronic pathological changes, is associated with the impairment of liver regeneration. Their association was discussed above.

Hepatitis, cirrhosis and hepatic fibrosis, the most common pathological changes in the liver, negatively affect liver regeneration. $\mathrm{T}$ cell-mediated hepatitis leads to reduced liver regeneration via altered expression levels of certain cytokines and associated signaling molecules, for example the upregulated expression of p21, Smad2, TGF- $\beta$ and IFN- $\gamma$, and downregulated expression of cyclin $\mathrm{D}$ and activation of Stat3 (20). In addition to the involvement of cytokines, other factors are associated with impaired regeneration in liver disease models. For example, hypoxia in hepatocytes caused by cirrhosis suppresses the hepatocyte proliferation induced by HGF and c-Met in vivo (154). The activation of HSCs, the primary cause of hepatic fibrosis, also inhibits liver regeneration and can be attenuated by STI-571 (155).

The consumption of ethanol, which leads to ethanol-induced liver injury, is another common harmful factor affecting liver regeneration. Long-term ethanol intake inhibits hepatic DNA synthesis following $\mathrm{PH}$, which is associated with a change in hepatocyte sensitivity to TNF (156). Acute and chronic ethanol consumption can inhibit liver regeneration by different mechanisms. The suppression of rat liver regeneration by acute ethanol is accompanied by upregulated levels of p53, prohibitin and TGF $\beta-1$ (157). Prolonging of the activation of p42/44 MAPK and decreased expression of $\gamma$-aminobutyric acid transport protein are also involved in the damaged proliferation of hepatocytes $(158,159)$. By contrast, prothymosin- $\alpha$, p38 MAPK and p21 are associated with impaired liver regeneration following chronic ethanol administration $(158,160,161)$.

Fatty liver also exhibits impaired regenerative capacity. The over-phosphorylation of Stat-3, inhibition of Jun N-terminal kinase, and decreased expression of NF- $\mathrm{KB}$ and cyclinD1 were found to be associated with the inhibition of proliferation in mouse nonalcoholic fatty liver disease models following PH (162). Furthermore, enhanced activation of STAT3 was found to be positively correlated with the levels of p21 in the regenerating process of fatty liver models (65).

The administration of drugs is another common factor in liver injury and the inhibition of liver regeneration. For example, amiloride, a weak diuretic and inhibitor of $\mathrm{Na}^{+} / \mathrm{H}^{+}$ exchange, has the ability to suppress DNA synthesis of proliferating hepatocytes in vitro and in vivo $(163,164)$. The amiloride 
analog, 5-(N, N-hexamethylene)-amiloride, another inhibitor of $\mathrm{Na}^{+} / \mathrm{H}^{+}$exchange, not only inhibits DNA synthesis, but also leads to apoptosis of hepatocytes in the rat liver following PH. Induction of the p53/p21 pathway is associated with the inhibitory function of 5-(N, N-hexamethylene)-amiloride (164).

The toxicity caused by intake of certain microelements can also damage liver regeneration. For example, selenium, a non-metal element, was shown to arrest DNA synthesis and cell cycle in rat PH models, which may be associated with the reduction of glutathione (165). Cadmium, a heavy metal element, is also harmful to liver regeneration involving inhibition of the enzymatic activity of thymidine kinase (166).

\section{Other inhibitors of liver regeneration}

There are certain proliferation inhibitors, which cannot be classified into the categories mentioned above. Regucalcin, a $\mathrm{Ca}^{2+}$-binding protein, was found to be downregulated in the rat liver at 1-3 days post-PH. Inhibition of nuclear DNA synthesis was found to be caused by regucalcin in hepatocytes isolated from PH rats, and $\mathrm{Ca}^{2+}$ treatment $(1.0-25 \mu \mathrm{M})$, which led to a similar result, indicated the negative effect for regucalcin in liver regeneration (167).

Peroxisome proliferator-activated receptor- $\gamma$ (PPAR- $\gamma)$, a nuclear receptor, which induces cell-cycle arrest and apoptosis in tumor cells, appears to have a negative correlation with liver regeneration (168). The expression of PPAR- $\gamma$ was found to decrease in the rat liver at $24 \mathrm{~h}$ and increase at $48-120 \mathrm{~h}$ post-PH, whereas the consumption of pioglitazone, a PPAR- $\gamma$ agonist, suppressed the proliferation of liver cells.

Vitamin D3 upregulated protein 1 (VDUP1), a regulator of cellular metabolism and endoplasmic reticulum (ER) stress, is also a suppressor of cell proliferation in various types of tumor. A previous study showed that VDUP1 was negatively correlated with liver regeneration (169). Enhanced proliferative responses were observed in the process of liver regeneration in VDUP1-knockout mice. The increased expression of cell-cycle proteins and the activation of proliferative signals appeared earlier in the VDUP1-knockout mice following PH.

Transmembrane and ubiquitin-like domain containing 1 (Tmub1), a novel gene, which is upregulated in the early stage of liver regeneration, was shown to have a negative effect in IL-6-induced hepatocyte proliferation via its interaction with calcium modulating cyclophilin ligand in vitro (72). Another study showed that the expression of Tmub1 may be regulated by IL-6 and C/EBP $\beta$ (170).

\section{Conclusion and outlook}

Proliferation-inhibiting signals are active in the entire process of liver regeneration, a number of which are induced in the early stage of liver regeneration when the cells are engaged in proliferation. In addition, the expression of other inhibitors are decreased at the same phase, but increased following peak proliferation. They contribute to control of the degree of regeneration and prevent oncogenesis through different mechanisms, with the function of proliferation-inhibiting pathways being as important as proliferation-promoting signals in liver regeneration.
However, knowledge of the proliferation-inhibiting pathways remains less than that of the proliferation-promoting pathways in liver regeneration. The majority of the signaling pathways described above remain to be fully elucidated. A focus is required on the elucidation of proliferation-inhibiting pathways. The identification of additional proliferation inhibitors, together with their upstream and downstream molecules, is required, as is an emphasis on the association between pro-proliferation and anti-proliferation signals.

\section{Acknowledgements}

This study was supported by a grant from the Natural Science Foundation of China (grant no. 81400651).

\section{References}

1. Jia C: Advances in the regulation of liver regeneration. Expert Rev Gastroenterol Hepatol 5: 105-121, 2011.

2. Elliott J: SOCS3 in liver regeneration and hepatocarcinoma. Mol Interv 8: 19-21, 2008.

3. Willenbring H, Sharma AD, Vogel A, Lee AY, Rothfuss A, Wang Z, Finegold $M$ and Grompe M: Loss of p21 permits carcinogenesis from chronically damaged liver and kidney epithelial cells despite unchecked apoptosis. Cancer cell 14: 59-67, 2008.

4. Nakamura T, Tomita Y, Hirai R, Yamaoka K, Kaji K and Ichihara A: Inhibitory effect of transforming growth factor-beta on DNA synthesis of adult rat hepatocytes in primary culture. Biochem Biophys Res Commun 133: 1042-1050, 1985.

5. Russell WE, Coffey RJ Jr, Ouellette AJ and Moses HL: Type beta transforming growth factor reversibly inhibits the early proliferative response to partial hepatectomy in the rat. Proc Natl Acad Sci USA 85: 5126-5130, 1988.

6. Liska V, Treska V, Mirka H, Kobr J, Sykora R, Skalicky T, Sutnar A, Vycital O, Bruha J, Pitule P, et al: Inhibition of transforming growth factor beta-1 augments liver regeneration after partial portal vein ligation in a porcine experimental model. Hepatogastroenterology 59: 235-240, 2012.

7. Karkampouna S, Goumans MJ, Ten Dijke P, Dooley S and Kruithof-de Julio M: Inhibition of TGF $\beta$ type I receptor activity facilitates liver regeneration upon acute $\mathrm{CCl}$ intoxication in mice. Arch Toxicol 90: 347-357, 2016.

8. Braun L, Mead JE, Panzica M, Mikumo R, Bell GI and Fausto N: Transforming growth factor beta mRNA increases during liver regeneration: A possible paracrine mechanism of growth regulation. Proc Natl Acad Sci USA 85: 1539-1543, 1988.

9. Fausto N, Mead JE, Braun L, Thompson NL, Panzica M, Goyette M, Bell GI and Shank PR: Proto-oncogene expression and growth factors during liver regeneration. Symp Fundam Cancer Res 39: 69-86, 1986.

10. Bissell DM, Wang SS, Jarnagin WR and Roll FJ: Cell-specific expression of transforming growth factor-beta in rat liver. Evidence for autocrine regulation of hepatocyte proliferation. J Clin Invest 96: 447-455, 1995.

11. Nishikawa Y, Wang M and Carr BI: Changes in TGF-beta receptors of rat hepatocytes during primary culture and liver regeneration: Increased expression of TGF-beta receptors associated with increased sensitivity to TGF-beta-mediated growth inhibition. J Cell Physiol 176: 612-623, 1998.

12. Jakowlew SB, Mead JE, Danielpour D, Wu J, Roberts AB and Fausto N: Transforming growth factor-beta (TGF-beta) isoforms in rat liver regeneration: Messenger RNA expression and activation of latent TGF-beta. Cell Regul 2: 535-548, 1991.

13. Bottinger EP, Factor VM, Tsang ML, Weatherbee JA, Kopp JB, Qian SW, Wakefield LM, Roberts AB, Thorgeirsson SS and Sporn MB: The recombinant proregion of transforming growth factor beta1 (latency-associated peptide) inhibits active transforming growth factor beta 1 in transgenic mice. Proc Natl Acad Sci USA 93: 5877-5882, 1996.

14. Strain AJ, Frazer A, Hill DJ and Milner RD: Transforming growth factor beta inhibits DNA synthesis in hepatocytes isolated from normal and regenerating rat liver. Biochem Biophys Res Commun 145: 436-442, 1987. 
15. Miyazono K, Kusanagi K and Inoue H: Divergence and convergence of TGF-beta/BMP signaling. J Cell Physiol 187: 265-276, 2001.

16. Attisano L and Wrana JL: Signal transduction by the TGF-beta superfamily. Science 296: 1646-1647, 2002.

17. Pañeda C, Gorospe I, Herrera B, Nakamura T, Fabregat I and Varela-Nieto I: Liver cell proliferation requires methionine adenosyltransferase 2A mRNA up-regulation. Hepatology 35 1381-1391, 2002.

18. Ten Dijke P, Goumans MJ, Itoh F and Itoh S: Regulation of cell proliferation by Smad proteins. J Cell Physiol 191: 1-16, 2002.

19. Macias-Silva M, Li W, Leu JI, Crissey MA and Taub R: Up-regulated transcriptional repressors SnoN and Ski bind Smad proteins to antagonize transforming growth factor-beta signals during liver regeneration. J Biol Chem 277: 28483-28490, 2002.

20. Hines IN, Kremer M, Isayama F, Perry AW, Milton RJ, Black AL, Byrd CL and Wheeler MD: Impaired liver regeneration and increased oval cell numbers following $\mathrm{T}$ cell-mediated hepatitis. Hepatology 46: 229-241, 2007.

21. Zhong Z, Tsukada S, Rehman H, Parsons CJ, Theruvath TP Rippe RA, Brenner DA and Lemasters JJ: Inhibition of transforming growth factor-beta/Smad signaling improves regeneration of small-for-size rat liver grafts. Liver Transpl 16 181-190, 2010

22. Schrum LW, Bird MA, Salcher O, Burchardt ER, Grisham JW, Brenner DA, Rippe RA and Behrns KE: Autocrine expression of activated transforming growth factor-beta(1) induces apoptosis in normal rat liver. Am J Physiol Gastrointest Liver Physiol 280: G139-G148, 2001

23. Hayashi H, Sakai K, Baba H and Sakai T: Thrombospondin-1 is a novel negative regulator of liver regeneration after partial hepatectomy through transforming growth factor-betal activation in mice. Hepatology 55: 1562-1573, 2012.

24. Gohda E, Matsunaga T, Kataoka $\mathrm{H}$ and Yamamoto I: TGF-beta is a potent inhibitor of hepatocyte growth factor secretion by human fibroblasts. Cell Biol Int Rep 16: 917-926, 1992.

25. Satoh M and Yamazaki M: Tumor necrosis factor stimulates DNA synthesis of mouse hepatocytes in primary culture and is suppressed by transforming growth factor beta and interleukin 6. J Cell Physiol 150: 134-139, 1992.

26. Bouzahzah B, Fu M, Iavarone A, Factor VM, Thorgeirsson SS and Pestell RG: Transforming growth factor-beta1 recruits histone deacetylase 1 to a p130 repressor complex in transgenic mice in vivo. Cancer Res 60: 4531-4537, 2000

27. Moriuchi A, Hirono S, Ido A, Ochiai T, Nakama T, Uto H, Hori T, Hayashi $\mathrm{K}$ and Tsubouchi $\mathrm{H}$ : Additive and inhibitory effects of simultaneous treatment with growth factors on DNA synthesis through MAPK pathway and G1 cyclins in rat hepatocytes. Biochem Biophys Res Commun 280: 368-373, 2001

28. Takiya S, Tagaya T, Takahashi K, Kawashima H, Kamiya M, Fukuzawa Y, Kobayashi S, Fukatsu A, Katoh K and Kakumu S: Role of transforming growth factor beta 1 on hepatic regeneration and apoptosis in liver diseases. J Clin Pathol 48: 1093-1097, 1995

29. Ueberham E, Löw R, Ueberham U, Schönig K, Bujard H and Gebhardt R: Conditional tetracycline-regulated expression of TGF-betal in liver of transgenic mice leads to reversible intermediary fibrosis. Hepatology 37: 1067-1078, 2003.

30. Leu JI, Crissey MA and Taub R: Massive hepatic apoptosis associated with TGF-beta1 activation after Fas ligand treatment of IGF binding protein-1-deficient mice. J Clin Invest 111 $129-139,2003$

31. Samson CM, Schrum LW, Bird MA, Lange PA, Brenner DA Rippe RA and Behrns KE: Transforming growth factor-betal induces hepatocyte apoptosis by a c-Jun independent mechanism. Surgery 132: 441-449, 2002.

32. Albright CD, Salganik RI, Craciunescu CN, Mar MH and Zeisel SH: Mitochondrial and microsomal derived reactive oxygen species mediate apoptosis induced by transforming growth factor-betal in immortalized rat hepatocytes. J Cell Biochem 89: 254-261, 2003.

33. Villevalois-Cam L, Rescan C, Gilot D, Ezan F, Loyer P, Desbuquois B, Guguen-Guillouzo C and Baffet G: The hepatocyte is a direct target for transforming-growth factor beta activation via the insulin-like growth factor II/mannose 6-phosphate receptor. J Hepatol 38: 156-163, 2003.

34. Yasuda H, Mine T, Shibata H, Eto Y, Hasegawa Y, Takeuchi T, Asano S and Kojima I: Activin A: An autocrine inhibitor of initiation of DNA synthesis in rat hepatocytes. J Clin Invest 92: 1491-1496, 1993.
35. Schwall RH, Robbins K, Jardieu P, Chang L, Lai C and Terrell TG: Activin induces cell death in hepatocytes in vivo and in vitro. Hepatology 18: 347-356, 1993

36. Hillier SG and Miró F: Inhibin, activin, and follistatin. Potential roles in ovarian physiology. Ann N Y Acad Sci 687: 29-38, 1993

37. Kogure K, Zhang YQ, Kanzaki M, Omata W, Mine T and Kojima I: Intravenous administration of follistatin: Delivery to the liver and effect on liver regeneration after partial hepatectomy. Hepatology 24: 361-366, 1996.

38. Ichikawa T, Zhang YQ, Kogure K, Hasegawa Y, Takagi H, Mori $\mathrm{M}$ and Kojima I: Transforming growth factor beta and activin tonically inhibit DNA synthesis in the rat liver. Hepatology 34: 918-925, 2001.

39. Takahashi H, Takeshita T and Yokomuro K: Suppression of liver regeneration resulting from intravenous injection of splenic glass adherent cells activated by poly I:C. Immunobiology 176 217-227, 1988.

40. Nakamura T, Arakaki R and Ichihara A: Interleukin-1 beta is a potent growth inhibitor of adult rat hepatocytes in primary culture. Exp Cell Res 179: 488-497, 1988.

41. Ichihara A: Growth and differentiation of neonatal rat hepatocytes in primary culture. Nihon Sanka Fujinka Gakka Zasshi 41: 1021-1026, 1989 (In Japanese).

42. Ichihara A: Mechanisms controlling growth of hepatocytes in primary culture. Dig Dis Sci 36: 489-493, 1991

43. Beyer HS and Theologides A: Tumor necrosis factor-alpha is a direct hepatocyte mitogen in the rat. Biochem Mol Biol Int 29: $1-4,1993$.

44. Okamura N, Tsukada K, Sakaguchi T, Ohtake M, Yoshida K and Muto T: Enhanced liver regeneration by FK 506 can be blocked by interleukin-1 alpha and interleukin-2. Transplant Proc 24: 413-415, 1992

45. Nagata Y, Tanaka N and Orita K: Endotoxin-induced liver injury after extended hepatectomy and the role of Kupffer cells in the rat. Surg Today 24: 441-448, 1994.

46. Boulton R, Woodman A, Calnan D, Selden C, Tam F and Hodgson $\mathrm{H}$ : Nonparenchymal cells from regenerating rat liver generate interleukin-1alpha and -1beta: A mechanism of negative regulation of hepatocyte proliferation. Hepatology 26 49-58, 1997

47. Scotte M, Masson S, Lyoumi S, Hiron M, Ténière P, Lebreton JP and Daveau M: Cytokine gene expression in liver following minor or major hepatectomy in rat. Cytokine 9: 859-867, 1997.

48. Uemura T, Miyazaki M, Hirai R, Matsumoto H, Ota T, Ohashi R, Shimizu N, Tsuji T, Inoue Y and Namba M: Different expression of positive and negative regulators of hepatocyte growth in growing and shrinking hepatic lobes after portal vein branch ligation in rats. Int J Mol Med 5: 173-179, 2000.

49. Stärkel P, Lambotte L, Sempoux C, De Saeger C, Saliez A, Maiter D and Horsmans Y: After portal branch ligation in the rat, cellular proliferation is associated with selective induction of c-Ha-ras, p53, cyclin E, and Cdk2. Gut 49: 119-130, 2001.

50. Anderson SP, Yoon L, Richard EB, Dunn CS, Cattley RC and Corton JC: Delayed liver regeneration in peroxisome proliferator-activated receptor-alpha-null mice. Hepatology 36: 544-554, 2002.

51. Tsutsumi R, Kamohara Y, Eguchi S, Azuma T, Fujioka H, Okudaira S, Yanaga K and Kanematsu T: Selective suppression of initial cytokine response facilitates liver regeneration after extensive hepatectomy in rats. Hepatogastroenterology 51: 701-704, 2004

52. Hou Z, Yanaga K, Kamohara Y, Eguchi S, Tsutsumi R, Furui $\mathrm{J}$ and Kanematsu T: A new suppressive agent against interleukin-1beta and tumor necrosis factor-alpha enhances liver regeneration after partial hepatectomy in rats. Hepatol Res 26 40-46, 2003

53. Zhu RZ, Xiang D, Xie C, Li JJ, Hu JJ, He HL, Yuan YS, Gao J, Han $\mathrm{W}$ and $\mathrm{Yu}$ Y: Protective effect of recombinant human IL-1Ra on CCl4-induced acute liver injury in mice. World J Gastroenterol 16: 2771-2779, 2010.

54. Goss JA, Mangino MJ and Flye MW: Kupffer cell autoregulation of IL-1 production by PGE2 during hepatic regeneration J Surg Res 52: 422-428, 1992

55. Goss JA, Mangino MJ, Callery MP and Flye MW: Prostaglandin E2 downregulates Kupffer cell production of IL-1 and IL-6 during hepatic regeneration. Am J Physiol 264: G601-G608, 1993.

56. Higashitsuji H, Arii S, Furutani M, Mise M, Monden K, Fujita S Ishiguro S, Kitao T, Nakamura T, Nakayama H, et al: Expression of cytokine genes during liver regeneration after partial hepatectomy in rats. J Surg Res 58: 267-274, 1995. 
57. Sgroi A, Gonelle-Gispert C, Morel P, Baertschiger RM, Niclauss N, Mentha G, Majno P, Serre-Beinier V and Buhler L: Interleukin-1 receptor antagonist modulates the early phase of liver regeneration after partial hepatectomy in mice. PLoS One 6: e25442, 2011.

58. Zheng YB, Zhang XH, Huang ZL, Lin CS, Lai J, Gu YR, Lin BL, Xie DY, Xie SB, Peng L and Gao ZL: Amniotic-fluid-derived mesenchymal stem cells overexpressing interleukin-1 receptor antagonist improve fulminant hepatic failure. PLoS One 7: e41392, 2012.

59. Franco-Gou R, Roselló-Catafau J, Casillas-Ramirez A, Massip-Salcedo M, Rimola A, Calvo N, Bartrons R and Peralta C: How ischaemic preconditioning protects small liver grafts. J Pathol 208: 62-73, 2006.

60. Zhao Y, Meng C, Wang Y, Huang H, Liu W, Zhang JF, Zhao H, Feng B, Leung PS and Xia Y: IL- $1 \beta$ inhibits $\beta$-Klotho expression and FGF19 signaling in hepatocytes. Am J Physiol Endocrinol Metab 310: E289-E300, 2016.

61. Streetz KL, Luedde T, Manns MP and Trautwein C: Interleukin 6 and liver regeneration. Gut 47: 309-312, 2000

62. Sun R, Jaruga B, Kulkarni S, Sun H and Gao B: IL-6 modulates hepatocyte proliferation via induction of $\mathrm{HGF} / \mathrm{p} 21 \mathrm{cip} 1$ : Regulation by SOCS3. Biochem Biophys Res Commun 338: 1943-1949, 2005

63. Kamohara Y, Sugiyama N, Mizuguchi T, Inderbitzin D, Lilja H, Middleton Y, Neuman T, Demetriou AA and Rozga J: Inhibition of signal transducer and activator transcription factor 3 in rats with acute hepatic failure. Biochem Biophys Res Commun 273: 129-135, 2000.

64. Wustefeld T, Rakemann T, Kubicka S, Manns MP and Trautwein C: Hyperstimulation with interleukin 6 inhibits cell cycle progression after hepatectomy in mice. Hepatology 32 514-522, 2000.

65. Torbenson M, Yang SQ, Liu HZ, Huang J, Gage W and Diehl AM: STAT-3 overexpression and p21 up-regulation accompany impaired regeneration of fatty livers. Am J Pathol 161: 155-161, 2002.

66. Quétier I, Brezillon N, Duriez M, Massinet H, Giang E, Ahodantin J, Lamant C, Brunelle MN, Soussan P and Kremsdorf D: Hepatitis B virus HBx protein impairs liver regeneration through enhanced expression of IL-6 in transgenic mice. J Hepatol 59: 285-291, 2013.

67. Kakumu S, Fukatsu A, Shinagawa T, Kurokawa S and Kusakabe A: Localisation of intrahepatic interleukin 6 in patients with acute and chronic liver disease. J Clin Pathol 45 408-411, 1992.

68. Napoli J, Bishop GA and McCaughan GW: Increased intrahepatic messenger RNA expression of interleukins 2, 6, and 8 in human cirrhosis. Gastroenterology 107: 789-798, 1994.

69. Malaguarnera M, Di Fazio I, Romeo MA, Restuccia S, Laurino A and Trovato BA: Elevation of interleukin 6 levels in patients with chronic hepatitis due to hepatitis $\mathrm{C}$ virus. J Gastroenterol 32: 211-215, 1997.

70. Tangkijvanich P, Vimolket T, Theamboonlers A, Kullavanijaya P, Suwangool $\mathrm{P}$ and Poovorawan Y: Serum interleukin- 6 and interferon-gamma levels in patients with hepatitis B-associated chronic liver disease. Asian Pac J Allergy Immunol 18: 109-114, 2000.

71. Suh HN, Lee SH, Lee MY, Lee YJ, Lee JH and Han HJ: Role of Interleukin-6 in the control of DNA synthesis of hepatocytes: Involvement of PKC, p44/42 MAPKs, and PPARdelta. Cell Physiol Biochem 22: 673-684, 2008.

72. Liu M, Liu H, Wang X, Chen P and Chen H: IL-6 induction of hepatocyte proliferation through the Tmubl-regulated gene pathway. Int J Mol Med 29: 1106-1112, 2012.

73. Campbell JS, Prichard L, Schaper F, Schmitz J, Stephenson-Famy A, Rosenfeld ME, Argast GM, Heinrich PC and Fausto N: Expression of suppressors of cytokine signaling during liver regeneration. J Clin Invest 107: 1285-1292, 2001.

74. Sakuda S, Tamura S, Yamada A, Miyagawa Ji, Yamamoto K, Kiso S, Ito N, Imanaka K, Wada A, Naka T, et al: Activation of signal transducer and activator transcription 3 and expression of suppressor of cytokine signal 1 during liver regeneration in rats J Hepatol 36: 378-384, 2002

75. Luedde T, Wuestefeld $\mathrm{T}$ and Trautwein C: A new player in the team: SOCS-3 socks it to cytokine signaling in the regenerating liver. Hepatology 34: 1254-1256, 2001

76. Heinrich PC, Behrmann I, Haan S, Hermanns HM, Müller-Newen G and Schaper F: Principles of interleukin (IL)-6-type cytokine signalling and its regulation. Biochem J 374: 1-20, 2003
77. Riehle KJ, Campbell JS, McMahan RS, Johnson MM, Beyer RP, Bammler TK and Fausto N: Regulation of liver regeneration and hepatocarcinogenesis by suppressor of cytokine signaling 3 . J Exp Med 205: 91-103, 2008.

78. Seki E, Kondo Y, Iimuro Y, Naka T, Son G, Kishimoto T, Fujimoto J, Tsutsui $H$ and Nakanishi K: Demonstration of cooperative contribution of MET- and EGFR-mediated STAT3 phosphorylation to liver regeneration by exogenous suppressor of cytokine signalings. J Hepatol 48: 237-245, 2008.

79. Brand S, Dambacher J, Beigel F, Zitzmann K, Heeg MH, Weiss TS, Prüfer T, Olszak T, Steib CJ, Storr M, et al: IL-22-mediated liver cell regeneration is abrogated by SOCS-1/3 overexpression in vitro. Am J Physiol Gastrointest Liver Physiol 292: G1019-G1028, 2007.

80. Yang XP, Schaper F, Teubner A, Lammert F, Heinrich PC, Matern $S$ and Siewert E: Interleukin-6 plays a crucial role in the hepatic expression of SOCS3 during acute inflammatory processes in vivo. J Hepatol 43: 704-710, 2005.

81. Aydemir TB, Chang SM, Guthrie GJ, Maki AB, Ryu MS, Karabiyik A and Cousins RJ: Zinc transporter ZIP14 functions in hepatic zinc, iron and glucose homeostasis during the innate immune response (endotoxemia). PLoS One 7: e48679, 2012.

82. Gui Y, Yeganeh M, Ramanathan S, Leblanc C, Pomerleau V, Ferbeyre G, Saucier C and Ilangumaran S: SOCS1 controls liver regeneration by regulating HGF signaling in hepatocytes. J Hepatol 55: 1300-1308, 2011.

83. Sun R, Park O, Horiguchi N, Kulkarni S, Jeong WI, Sun HY, Radaeva S and Gao B: STAT1 contributes to dsRNA inhibition of liver regeneration after partial hepatectomy in mice. Hepatology 44: 955-966, 2006.

84. Yin S, Wang H, Bertola A, Feng D, Xu MJ, Wang Y and Gao B: Activation of invariant natural killer T cells impedes liver regeneration by way of both IFN- $\gamma$ - and IL-4-dependent mechanisms. Hepatology 60: 1356-1366, 2014.

85. Cosgrove BD, Cheng C, Pritchard JR, Stolz DB Lauffenburger DA and Griffith LG: An inducible autocrine cascade regulates rat hepatocyte proliferation and apoptosis responses to tumor necrosis factor-alpha. Hepatology 48: 276-288, 2008.

86. Theocharis SE, Margeli AP and Tsokos MG: Alpha 2b-interferon inhibits rat liver regeneration after partial hepatectomy without affecting thymidine kinase activity. J Lab Clin Med 125: 588-596, 1995

87. Theocharis SE, Margeli AP, Skaltsas SD, Skopelitou AS Mykoniatis MG and Kittas CN: Effect of interferon-alpha2b administration on rat liver regeneration after partial hepatectomy. Dig Dis Sci 42: 1981-1986, 1997.

88. Ogiso T, Nagaki M, Takai S, Tsukada Y, Mukai T, Kimura K and Moriwaki $\mathrm{H}$ : Granulocyte colony-stimulating factor impairs liver regeneration in mice through the up-regulation of interleukin-1beta. J Hepatol 47: 816-825, 2007.

89. Vaquero J, Campbell JS, Haque J, McMahan RS, Riehle KJ, Bauer RL and Fausto N: Toll-Like Receptor 4 and myeloid differentiation factor 88 provide mechanistic insights into the cause and effects of interleukin- 6 activation in mouse liver regeneration. Hepatology 54: 597-608, 2011.

90. Thompson NL, Mead JE, Braun L, Goyette M, Shank PR and Fausto N: Sequential protooncogene expression during rat liver regeneration. Cancer Res 46: 3111-3117, 1986.

91. Drazan KE, Shen XD, Csete ME, Zhang WW, Roth JA, Busuttil RW and Shaked A: In vivo adenoviral-mediated human p53 tumor suppressor gene transfer and expression in rat liver after resection. Surgery 116: 197-204, 1994.

92. Lennartsson P, Stenius U and Högberg J: p53 expression and TGF-alpha-induced replication of hepatocytes isolated from rats exposed to the carcinogen diethylnitrosamine. Cell Biol Toxicol 15: 31-39, 1999

93. Inoue Y, Tomiya T, Yanase M, Arai M, Ikeda H, Tejima K, Ogata I, Kimura S, Omata M and Fujiwara K: p53 May positively regulate hepatocyte proliferation in rats. Hepatology 36 : 336-344, 2002.

94. Tsuji K and Ogawa K: Recovery from ultraviolet-induced growth arrest of primary rat hepatocytes by p53 antisense oligonucleotide treatment. Mol Carcinog 9: 167-174, 1994.

95. Arora V, Iversen PL and Ebadi M: Manipulation of metallothionein expression in the regenerating rat liver using antisense oligonucleotides. Biochem Biophys Res Commun 246: 711-718, 1998.

96. Arora V and Iversen PL: Antisense oligonucleotides targeted to the p53 gene modulate liver regeneration in vivo. Drug Metab Dispos 28: 131-138, 2000. 
97. Kurinna S, Stratton SA, Coban Z, Schumacher JM, Grompe M, Duncan AW and Barton MC: p53 regulates a mitotic transcription program and determines ploidy in normal mouse liver. Hepatology 57: 2004-2013, 2013.

98. Zhang L, Liu L, He Z, Li G, Liu J, Song Z, Jin H, Rudolph KL, Yang $\mathrm{H}$, Mao Y, et al: Inhibition of wild-type p53-induced phosphatase 1 promotes liver regeneration in mice by direct activation of mammalian target of rapamycin. Hepatology 61 : 2030-2041, 2015

99. Ohlson LC, Koroxenidou L and Hällström IP: Inhibition of in vivo rat liver regeneration by 2 -acetylaminofluorene affects the regulation of cell cycle-related proteins. Hepatology 27: 691-696, 1998.

100. Stepniak E, Ricci R, Eferl R, Sumara G, Sumara I, Rath M, Hui L and Wagner EF: c-Jun/AP-1 controls liver regeneration by repressing p53/p21 and p38 MAPK activity. Genes Dev 20 2306-2314, 2006.

101. Li CC, Chu HY, Yang CW, Chou CK and Tsai TF: Aurora-A overexpression in mouse liver causes p53-dependent premitotic arrest during liver regeneration. Mol Cancer Res 7: 678-688, 2009.

102. Fan X, Jiang Y, Wang Y, Tan H, Zeng H, Wang Y, Chen P, Qu A, Gonzalez FJ, Huang M and Bi H: Wuzhi tablet (Schisandra Sphenanthera extract) protects against acetaminophen-induced hepatotoxicity by inhibition of CYP-mediated bioactivation and regulation of NRF2-ARE and p53/p21 pathways. Drug Metab Dispos 42: 1982-1990, 2014.

103. Wang Y, Jiang Y, Fan X, Tan H, Zeng H, Wang Y, Chen P, Huang $\mathrm{M}$ and $\mathrm{Bi} \mathrm{H}$ : Hepato-protective effect of resveratrol against acetaminophen-induced liver injury is associated with inhibition of CYP-mediated bioactivation and regulation of SIRT1-p53 signaling pathways. Toxicol Lett 236: 82-89, 2015.

104.Zeng H, Li D, Qin X, Chen P, Tan H, Zeng X, Li X, Fan X, Jiang Y, Zhou Y, et al: Hepatoprotective effects of schisandra sphenanthera extract against lithocholic acid-induced cholestasis in male mice are associated with activation of the pregnane $X$ receptor pathway and promotion of liver regeneration. Drug Metab Dispos 44: 337-342, 2016.

105. Shih TY and Weeks MO: Oncogenes and cancer: The p21 ras genes. Cancer Invest 2: 109-123, 1984

106. el-Deiry WS, Tokino T, Velculescu VE, Levy DB, Parsons R, Trent JM, Lin D, Mercer WE, Kinzler KW and Vogelstein B WAF1, a potential mediator of p53 tumor suppression. Cell 75 $817-825,1993$

107. Harper JW, Adami GR, Wei N, Keyomarsi K and Elledge SJ: The p21 Cdk-interacting protein Cip1 is a potent inhibitor of G1 cyclin-dependent kinases. Cell 75: 805-816, 1993.

108. Albrecht JH, Poon RY, Ahonen CL, Rieland BM, Deng C and Crary GS: Involvement of p21 and p27 in the regulation of CDK activity and cell cycle progression in the regenerating liver. Oncogene 16: 2141-2150, 1998.

109. Sasaki Y, Hayashi N, Morita Y, Ito T, Kasahara A, Fusamoto H, Sato N, Tohyama M and Kamada T: Cellular analysis of c-Ha-ras gene expression in rat liver after $\mathrm{CCl} 4$ administration. Hepatology 10: 494-500, 1989.

110. Hui TT, Mizuguchi T, Sugiyama N, Avital I, Rozga J and Demetriou AA: Immediate early genes and p21 regulation in liver of rats with acute hepatic failure. Am J Surg 183: 457-463, 2002.

111. Nango R, Terada C and Tsukamoto I: Jun N-terminal kinase activation and upregulation of p53 and p21(WAF1/CIP1) in selenite-induced apoptosis of regenerating liver. Eur J Pharmacol 471: 1-8, 2003.

112. Chang ML, Chen TH, Chang MY and Yeh CT: Cell cycle perturbation in the hepatocytes of $\mathrm{HCV}$ core transgenic mice following common bile duct ligation is associated with enhanced p21 expression. J Med Virol 81: 467-472, 2009.

113. Weymann A, Hartman E, Gazit V, Wang C, Glauber M, Turmelle Y and Rudnick DA: p21 is required for dextrose-mediated inhibition of mouse liver regeneration. Hepatology 50 207-215, 2009.

114. Lehmann K, Tschuor C, Rickenbacher A, Jang JH, Oberkofler CE, Tschopp O, Schultze SM, Raptis DA, Weber A, Graf R, et al: Liver failure after extended hepatectomy in mice is mediated by a p21-dependent barrier to liver regeneration. Gastroenterology 143: 1609-1619.e4, 2012.

115. Buitrago-Molina LE, Marhenke S, Longerich T, Sharma AD, Boukouris AE, Geffers R, Guigas B, Manns MP and Vogel A The degree of liver injury determines the role of p21 in liver regeneration and hepatocarcinogenesis in mice. Hepatology 58: $1143-1152,2013$
116. Albrecht JH, Meyer AH and Hu MY: Regulation of cyclin-dependent kinase inhibitor $\mathrm{p} 21$ (WAF1/Cip1/Sdi1) gene expression in hepatic regeneration. Hepatology 25: 557-563, 1997.

117. Serfas MS, Goufman E, Feuerman MH, Gartel AL and Tyner AL: p53-independent induction of p21WAF1/CIP1 expression in pericentral hepatocytes following carbon tetrachloride intoxication. Cell Growth Differ 8: 951-961, 1997.

118. Wu H, Wade M, Krall L, Grisham J, Xiong Y and Van Dyke T: Targeted in vivo expression of the cyclin-dependent kinase inhibitor p21 halts hepatocyte cell-cycle progression, postnatal liver development and regeneration. Genes Dev 10: 245-260, 1996.

119. Jaime M, Pujol MJ, Serratosa J, Pantoja C, Canela N, Casanovas O, Serrano M, Agell N and Bachs O: The p21(Cip1) protein, a cyclin inhibitor, regulates the levels and the intracellular localization of $\mathrm{CDC} 25 \mathrm{~A}$ in mice regenerating livers. Hepatology 35: 1063-1071, 2002.

120. Trautwein C, Will M, Kubicka S, Rakemann T, Flemming P and Manns MP: 2-acetaminofluorene blocks cell cycle progression after hepatectomy by p21 induction and lack of cyclin E expression. Oncogene 18: 6443-6453, 1999.

121. Fan X, Chen P, Tan H, Zeng H, Jiang Y, Wang Y, Wang Y, Hou X, Bi H and Huang M: Dynamic and coordinated regulation of KEAP1-NRF2-ARE and p53/p21 signaling pathways is associated with acetaminophen injury responsive liver regeneration. Drug Metab Dispos 42: 1532-1539, 2014

122. Timchenko NA, Harris TE, Wilde M, Bilyeu TA, Burgess-Beusse BL, Finegold MJ and Darlington GJ: CCAAT/enhancer binding protein alpha regulates p21 protein and hepatocyte proliferation in newborn mice. Mol Cell Biol 17: 7353-7361, 1997.

123. Vail ME, Chaisson ML, Thompson $\mathrm{J}$ and Fausto N: Bcl-2 expression delays hepatocyte cell cycle progression during liver regeneration. Oncogene 21: 1548-1555, 2002

124. Chen S, Zheng J, Hao Q, Yang S, Wang J, Chen H, Chen L, Zhou Y, Yu C, Jiao B and Cai Z: p53-insensitive PUMA down-regulation is essential in the early phase of liver regeneration after partial hepatectomy in mice. J Hepatol 52: 864-871, 2010.

125. Bailly-Maitre B, Bard-Chapeau E, Luciano F, Droin N, Bruey JM, Faustin B, Kress C, Zapata JM and Reed JC: Mice lacking bi-1 gene show accelerated liver regeneration. Cancer Res 67: 1442-1450, 2007.

126. Wyllie AH: Apoptosis and carcinogenesis. Eur J Cell Biol 73 189-197, 1997.

127. Kiba T, Saito S, Numata K and Sekihara H: Fas (APO-1/CD95) mRNA is down-regulated in liver regeneration after hepatectomy in rats. J Gastroenterol 35: 34-38, 2000.

128. Hu W, Fan C, Jiang P, Ma Z, Yan X, Di S, Jiang S, Li T, Cheng Y and Yang Y: Emerging role of N-myc downstream-regulated gene 2 (NDRG2) in cancer. Oncotarget 7: 209-223, 2016.

129. Yang JD, Li Y, Wu L, Zhang Z, Han T, Guo H, Jiang N, Tao K, Ti Z, Liu X, et al: NDRG2 in rat liver regeneration: Role in proliferation and apoptosis. Wound Repair Regen 18: 524-531, 2010.

130. Mischoulon D, Rana B, Bucher NL and Farmer SR: Growth-dependent inhibition of CCAAT enhancer-binding protein (C/EBP alpha) gene expression during hepatocyte proliferation in the regenerating liver and in culture. Mol Cell Biol 12: 2553-2560, 1992.

131. Iakova P, Awad SS and Timchenko NA: Aging reduces proliferative capacities of liver by switching pathways of C/EBPalpha growth arrest. Cell 113: 495-506, 2003.

132. Pauta M, Rotllan N, Fernández-Hernando A, Langhi C, Ribera J, Lu M, Boix L, Bruix J, Jimenez W, Suárez Y, et al: Akt-mediated foxol inhibition is required for liver regeneration. Hepatology 63: 1660-1674, 2016.

133. Chen X, Zhao Y, Wang F, Bei Y, Xiao J and Yang C: MicroRNAs in liver regeneration. Cell Physiol Biochem 37: 615-628, 2015.

134. Revuelta-Cervantes J, Mayoral R, Miranda S González-Rodríguez A, Fernández M, Martín-Sanz P and Valverde AM: Protein tyrosine phosphatase 1B (PTP1B) deficiency accelerates hepatic regeneration in mice. Am J Pathol 178: 1591-1604, 2011.

135. Hong L, Cai Y, Jiang M, Zhou D and Chen L: The Hippo signaling pathway in liver regeneration and tumorigenesis. Acta Biochim Biophys Sin (Shanghai) 47: 46-52, 2015.

136. Grijalva JL, Huizenga M, Mueller K, Rodriguez S, Brazzo J, Camargo F, Sadri-Vakili G and Vakili K: Dynamic alterations in Hippo signaling pathway and YAP activation during liver regeneration. Am J Physiol Gastrointest Liver Physiol 307: G196-G204, 2014 
137. Pondugula SR, Flannery PC, Apte U, Babu JR, Geetha T, Rege SD, Chen T and Abbott KL: Mg2+/Mn2+-dependent phosphatase $1 \mathrm{~A}$ is involved in regulating pregnane $\mathrm{X}$ receptor-mediated cytochrome p450 3A4 gene expression. Drug Metab Dispos 43: 385-391, 2015.

138. Keeton AB, Xu J, Franklin JL and Messina JL: Regulation of Gene33 expression by insulin requires MEK-ERK activation. Biochim Biophys Acta 1679: 248-255, 2004.

139. Ballaro C, Ceccarelli S, Tiveron C, Tatangelo L, Salvatore AM, Segatto $\mathrm{O}$ and Alemà $\mathrm{S}$ : Targeted expression of RALT in mouse skin inhibits epidermal growth factor receptor signalling and generates a Waved-like phenotype. EMBO Rep 6: 755-761, 2005.

140. Reschke M, Ferby I, Stepniak E, Seitzer N, Horst D, Wagner EF and Ullrich A: Mitogen-inducible gene-6 is a negative regulator of epidermal growth factor receptor signaling in hepatocytes and human hepatocellular carcinoma. Hepatology 51: 1383-1390, 2010.

141. Leffert HL and Weinstein DB: Growth control of differentiated fetal rat hepatocytes in primary monolayer culture. IX. Specific inhibition of DNA synthesis initiation by very low density lipoprotein and possible significance to the problem of liver regeneration. J Cell Biol 70: 20-32, 1976.

142. Chanda S and Mehendale HM: Nutritional impact on the final outcome of liver injury inflicted by model hepatotoxicants: Effect of glucose loading. FASEB J 9: 240-245, 1995.

143. Vazquez-Chantada M, Ariz U, Varela-Rey M, Embade N, Martínez-Lopez N, Fernández-Ramos D, Gómez-Santos L, Lamas S, Lu SC, Martínez-Chantar ML and Mato JM: Evidence for LKB1/AMP-activated protein kinase/endothelial nitric oxide synthase cascade regulated by hepatocyte growth factor, $\mathrm{S}$-adenosylmethionine, and nitric oxide in hepatocyte proliferation. Hepatology 49: 608-617, 2009.

144. Varela-Rey M, Beraza N, Lu SC, Mato JM and Martinez-Chantar ML: Role of AMP-activated protein kinase in the control of hepatocyte priming and proliferation during liver regeneration. Exp Biol Med (Maywood) 236: 402-408, 2011

145. Garcia-Rodriguez JL, Barbier-Torres L, Fernández-Álvarez S, Gutiérrez-de Juan V, Monte MJ, Halilbasic E, Herranz D, Álvarez L, Aspichueta P, Marín JJ, et al: SIRT1 controls liver regeneration by regulating bile acid metabolism through farnesoid $\mathrm{X}$ receptor and mammalian target of rapamycin signaling. Hepatology 59: 1972-1983, 2014.

146. Leffert HL: Growth control of differentiated fetal rat hepatocytes in primary monolayer culture. VII. Hormonal control of DNA synthesis and its possible significance to the problem of liver regeneration. J Cell Biol 62: 792-801, 1974.

147. Houck KA, Cruise JL and Michalopoulos G: Norepinephrine modulates the growth-inhibitory effect of transforming growth factor-beta in primary rat hepatocyte cultures. J Cell Physiol 135: 551-555, 1988

148. Barbason H, Bouzahzah B, Herens C, Marchandise J, Sulon J and Van Cantfort J: Circadian synchronization of liver regeneration in adult rats: The role played by adrenal hormones. Cell Tissue Kinet 22: 451-460, 1989.

149. Spector MS, Auer KL, Jarvis WD, Ishac EJ, Gao B, Kunos G and Dent P: Differential regulation of the mitogen-activated protein and stress-activated protein kinase cascades by adrenergic agonists in quiescent and regenerating adult rat hepatocytes. Mol Cell Biol 17: 3556-3565, 1997.

150. Krasil'nikov MA, Bogdanova NN and Adler VV: Inhibition of proliferation of normal and neoplastic liver cells under conditions of prolonged hormonal stimulation. Biokhimiia 54: 656-661, 1989 (In Russian).

151. Nagy P, Kiss A, Schnur J and Thorgeirsson SS: Dexamethasone inhibits the proliferation of hepatocytes and oval cells but not bile duct cells in rat liver. Hepatology 28: 423-429, 1998.

152. Yager JD, Zurlo J, Sewall CH, Lucier GW and He H: Growth stimulation followed by growth inhibition in livers of female rats treated with ethinyl estradiol. Carcinogenesis 15: 2117-2123, 1994.
153. Kokudo N, Kothary PC, Eckhauser FE, Nakamura T and Raper SE: Inhibition of DNA synthesis by somatostatin in rat hepatocytes stimulated by hepatocyte growth factor or epidermal growth factor. Am J Surg 163: 169-173, 1992.

154. Corpechot C, Barbu V, Wendum D, Chignard N, Housset C, Poupon R and Rosmorduc O: Hepatocyte growth factor and c-Met inhibition by hepatic cell hypoxia: A potential mechanism for liver regeneration failure in experimental cirrhosis. Am J Pathol 160: 613-620, 2002.

155. Kuo WL, Yu MC, Lee JF, Tsai CN, Chen TC and Chen MF: Imatinib mesylate improves liver regeneration and attenuates liver fibrogenesis in CCL4-treated mice. J Gastrointest Surg 16: 361-369, 2012

156. Akerman PA, Cote PM, Yang SQ, McClain C, Nelson S, Bagby $\mathrm{G}$ and Diehl AM: Long-term ethanol consumption alters the hepatic response to the regenerative effects of tumor necrosis factor-alpha. Hepatology 17: 1066-1073, 1993.

157. Lumpkin CK Jr, Moore TL, Tarpley MD, Taylor JM, Badger TM and McClung JK: Acute ethanol and selected growth suppressor transcripts in regenerating rat liver. Alcohol 12: 357-362, 1995.

158. Chen J, Ishac EJ, Dent P, Kunos G and Gao B: Effects of ethanol on mitogen-activated protein kinase and stress-activated protein kinase cascades in normal and regenerating liver. Biochem J 334: 669-676, 1998.

159. Zhang MN, Gong Y and Minuk GY: The effects of acute ethanol exposure on inhibitors of hepatic regenerative activity in the rat. Mol Cell Biochem 207: 109-114, 2000.

160. Silverman AL, Smith MR, Sasaki D, Mutchnick MG and Diehl AM: Altered levels of prothymosin immunoreactive peptide, a growth-related gene product, during liver regeneration after chronic ethanol feeding. Alcohol Clin Exp Res 18: 616-619, 1994.

161. Koteish A, Yang S, Lin H, Huang J and Diehl AM: Ethanol induces redox-sensitive cell-cycle inhibitors and inhibits liver regeneration after partial hepatectomy. Alcohol Clin Exp Res 26: 1710-1718, 2002.

162. Yang SQ, Lin HZ, Mandal AK, Huang J and Diehl AM: Disrupted signaling and inhibited regeneration in obese mice with fatty livers: Implications for nonalcoholic fatty liver disease pathophysiology. Hepatology 34: 694-706, 2001

163. Koch KS and Leffert HL: Increased sodium ion influx is necessary to initiate rat hepatocyte proliferation. Cell 18: 153-163, 1979.

164. Ramalho FS, Ramalho LN, Castro-E-Silva Júnior O, Zucoloto S and Corrêa FM: Angiotensin-converting enzyme inhibition by lisinopril enhances liver regeneration in rats. Braz J Med Biol Res 34: 125-127, 2001.

165. LeBoeuf RA, Laishes BA and Hoekstra WG: Effects of selenium on cell proliferation in rat liver and mammalian cells as indicated by cytokinetic and biochemical analysis. Cancer Res 45: 5496-5504, 1985

166. Theocharis SE, Margeli AP, Spiliopoulou C, Skaltsas S, Kittas C and Koutselinis A: Hepatic stimulator substance administration enhances regenerative capacity of hepatocytes in cadmium-pretreated partially hepatectomized rats. Dig Dis Sci 41: 1475-1480, 1996.

167. Yamaguchi M and Kanayama Y: Calcium-binding protein regucalcin inhibits deoxyribonucleic acid synthesis in the nuclei of regenerating rat liver. Mol Cell Biochem 162: 121-126, 1996.

168. Yamamoto Y, Ono T, Dhar DK, Yamanoi A, Tachibana M, Tanaka T and Nagasue N: Role of peroxisome proliferator-activated receptor-gamma (PPARgamma) during liver regeneration in rats. J Gastroenterol Hepatol 23: 930-937, 2008.

169. Kwon HJ, Won YS, Yoon YD, Yoon WK, Nam KH, Choi IP, Kim DY and Kim HC: Vitamin D3 up-regulated protein 1 deficiency accelerates liver regeneration after partial hepatectomy in mice. J Hepatol 54: 1168-1176, 2011.

170. Liu M, Yuan T, Liu H and Chen P: CCAAT/enhancer-binding protein $\beta$ regulates interleukin- 6 -induced transmembrane and ubiquitin-like domain containing 1 gene expression in hepatocytes. Mol Med Rep 10: 2177-2183, 2014. 